\title{
Esophageal motility in men and women evaluated by high-resolution manometry
}

\author{
Tarciana Vieira COSTA ${ }^{1}$ and Roberto Oliveira DANTAS ${ }^{2}$
}

Received 5/10/2016 Accepted 14/11/2016

\begin{abstract}
Background - Esophageal motility has been described in the literature as having differences between men and women. Most of these investigations use the water perfusion method for esophageal manometry. In this investigation the esophageal motility of men and women was compared with high-resolution manometry of the esophagus. Objective - To compare the esophageal motility of men and women with the high-resolution manometry method for esophageal manometry, performed in the sitting position. The hypothesis was that men and women have differences in esophageal motility. Methods - High-resolution manometry was performed in normal volunteers, 10 men [mean age: 37.5 (8.1) years] and 12 women [mean age: 38.7 (7.5) years], in the sitting position and with 10 swallows of a $5 \mathrm{~mL}$ bolus of saline, with an interval of at least 30 seconds between consecutive swallows. We evaluated the integrated relaxation pressure of the lower esophageal sphincter, contraction front velocity, distal contraction integral, distal latency, proximal contraction extension, proximal contraction duration $>30 \mathrm{mmHg}$, proximal contraction duration, proximal contraction integral and maximal upper esophageal sphincter pressure. Results - There was no significant difference between men and women in the variables measured. Conclusion - There was no difference in esophageal motility of men and women evaluated by the high resolution manometry method, in the sitting position with swallows of a liquid bolus.
\end{abstract}

HEADINGS - Gastrointestinal motility. Manometry, methods. Sex factors.

\section{INTRODUCTION}

Previous publications have shown the possibility of differences between men and women in esophageal motility ${ }^{(11-14)}$. The results were found using different methods for esophageal motility evaluation, mainly by the water perfusion method. Nowadays high-resolution manometry (HRM) is the best way to perform this evaluation. It can give different parameters from the traditional water perfusion or solid state manometric methods ${ }^{(3,13)}$.

The investigations about gender influence on esophageal motility have described that: integrated relaxation pressure of the lower esophageal sphincter (LES) is higher in women than in men $^{(11)}$; contractions in proximal esophagus have a higher area under the curve in women ${ }^{(7)}$; women have an increase in contraction duration in distal esophagus ${ }^{(8)}$; women have a higher LES pressure, higher distal amplitude, longer distal contraction duration and slower distal velocity of peristaltic contraction ${ }^{(14)}$. Gender does not influence whether esophageal motility is normal, spastic or with a non-specific motor disorder ${ }^{(1)}$.

The confirmation of difference between men and women on esophageal motility is important in the definition of normal parameters and in the better understanding of esophageal physiology. Esophageal motility has the influence of body position ${ }^{(2,4,6,10,12)}$ and the characteristics of the swallowed bolus ${ }^{(2,5,6,10)}$, and may also have the influence of gender.

A previous evaluation of the effect of gender in esophageal motility with the method of HRM, with the main focus on distal esophagus, described the difference of high integrated relaxation pressure (IRP) in women compared with men as unique ${ }^{(11)}$, being measured in both supine and sitting positions and with a $5 \mathrm{~mL}$ saline bolus. In the present investigation our objective was to evaluate, by HRM in the sitting position and swallows of a $5 \mathrm{~mL}$ saline bolus, the proximal and distal esophageal motility in men and women, with the hypothesis that the esophageal contraction in women has some differences when compared with the esophageal contraction of men.

\section{METHODS}

The esophageal motility of 10 men with mean age 37.5 (8.1) years and 12 women with mean age 38.7 (7.5) years was evaluated (Table 1). Volunteers did not have any symptoms or any gastroenterologic, neurologic, endocrinologic diseases, previous surgery in the digestive tract and no disease at the time of the esophageal

TABLE 1. Men and women involved in the investigation. Mean (SD)

\begin{tabular}{lcc}
\hline & Men $(\mathrm{n}=10)$ & Women $(\mathrm{n}=12)$ \\
\hline Age (years) & $37.5(8.1)$ & $38.7(7.5)$ \\
Weight $(\mathrm{kg})$ & $82.8(13.9)$ & $79.2(13.3)$ \\
Height $(\mathrm{m})$ & $1.73(0.06)$ & $1.61(0.06)$ \\
BMI $(\mathrm{kg} / \mathrm{m} 2)$ & $27.6(3.6)$ & $30.4(3.8)$ \\
\hline
\end{tabular}

BMI: body mass index; SD: standard deviation. 
motility evaluation. The investigation was approved by the Human Research Committee of the University Hospital of Ribeirão Preto and all volunteers gave written informed consent to participate in the investigation.

The evaluation of esophageal motility was done with a 32-channel solid state catheter and the InSIGHT High Resolution Impedance Manometry System (Sandhill Instruments, Highlands Ranch, CO, USA). After the calibration of the catheter at pressures 0 $\mathrm{mmHg}$ and $100 \mathrm{mmHg}$, with at least 6 hours of fasting and with the volunteers sitting on a chair, the manometric catheter was introduced via the nose until the distal channels were inside the stomach, in a position which permits the registration of the pressure from the pharynx to the stomach. After an enough time for the stabilization of the register, each volunteer performed, in the sitting position, 10 swallows of a $5 \mathrm{~mL}$ bolus of saline at room temperature, with an interval of at least 30 seconds between swallows. The volunteer performed only one swallow of each $5 \mathrm{~mL}$ bolus volume. Double swallows were excluded, and another swallow was performed.

Each examination was analyzed for the integrated relaxation pressure (IRP) of the lower esophageal sphincter, the contraction front velocity (CFV), distal contraction integral (DCI), distal latency (DL), proximal contraction extension (PCE), proximal contraction integral $(\mathrm{PCI})$, proximal contraction duration $>30$ $\mathrm{mmHg}(\mathrm{PCD}>30 \mathrm{mmHg})$, proximal contraction duration (PCD), and upper esophageal sphincter (UES) pressure. The method for measurement of each variable was previously described ${ }^{(3,10)}$.

Data were tested for normality using the Shapiro-Wilks test. To test the comparisons between men and women, a two-tailed Student's $t$ test was used in normal distribution data and the MannWhitney $U$ test in data which did not have normal distribution. The results are shown in mean, median, standard deviation (SD). A $P \leq 0.05$ was considered as significant.

\section{RESULTS}

There was no difference between men and women in all measurements performed (Table 2).

The IRP in women had a median of $8.2 \mathrm{mmHg}$ (limits: $1-18.1$ $\mathrm{mmHg}$ ), and men a median of $5.0 \mathrm{mmHg}$ (limits: $3.2-12.5 \mathrm{mmHg}$ ). Statistical analysis of these results did not find significance $(P=0.18$, Figure 1).

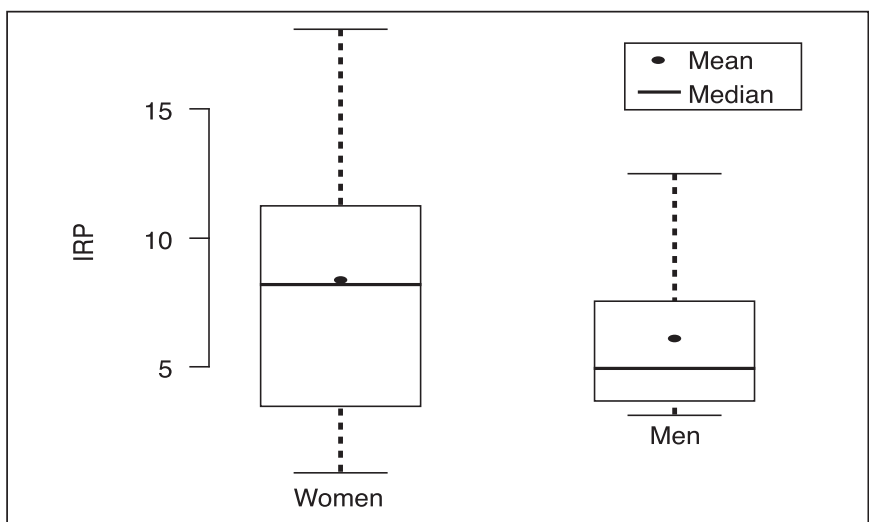

FIGURE 1. Box plot of the integrated relaxation pressure (IRP), in $\mathrm{mmHg}$, of men $(\mathrm{n}=10)$ and women $(\mathrm{n}=12)$.

\section{DISCUSSION}

In this investigation, using HRM and evaluation of the esophageal motility in the sitting position with low viscous liquid bolus, differences between men and women in esophageal motility were not found.

Esophageal motility is different when the individual is in the sitting or in the supine positions. In the sitting position the proportion of abnormal contractions increase ${ }^{(2,10,12)}$, the distal contraction integral and the amplitude of contractions decrease $\mathrm{e}^{(4,6,11,12)}$. It could be, at least in part, the explanation for the absence of difference between men and women. Esophageal manometric studies using the water perfusion method were performed in the supine position and in this investigation it was performed in the sitting position. The absence of difference found in the sitting position did not exclude the possibility of difference in another position. However, the results of comparison between men and women in esophageal motility using HRM found a higher integrated relaxation pressure (IRP) in women than in men in both positions ${ }^{(11)}$. The median of IRP in women was $9.01 \mathrm{mmHg}$ (95th percentile: $4.26-20.73 \mathrm{mmHg}$ ) and in men was $7.02 \mathrm{mmHg}$ (95th percentile: $3.26-14.68 \mathrm{mmHg}$, $P=0.04$ ) in the sitting position, and in the supine position it was $8.06 \mathrm{mmHg}$ (95th percentile: $4.04-18.96 \mathrm{mmHg}$ ) in women and $7.40 \mathrm{mmHg}$ (95th percentile: $4.16-14.46 \mathrm{mmHg}, P=0.04)$ in men.

TABLE 2. Results of high resolution esophageal manometry in men $(\mathrm{n}=10)$ and women $(\mathrm{n}=12)$

\begin{tabular}{|c|c|c|c|c|c|}
\hline & \multicolumn{2}{|c|}{ Men } & \multicolumn{2}{|c|}{ Women } & \multirow{2}{*}{$P$ value } \\
\hline & Mean (SD) & Median & Mean (SD) & Median & \\
\hline IRP $(\mathrm{mmHg})$ & $6.0(3.1)$ & 5.0 & $8.4(5.4)$ & 8.2 & 0.18 \\
\hline DCI (mmHg.s.cm) & $1441.6(1126.3)$ & 1355.3 & $913.8(735.8)$ & 803.8 & 0.15 \\
\hline $\mathrm{DL}(\mathrm{s})$ & $6.8(1.0)$ & 6.9 & $6.8(0.9)$ & 6.6 & 0.93 \\
\hline $\mathrm{PCD}>30 \mathrm{mHg}(\mathrm{s})$ & $2.0(0.8)$ & 1.8 & $1.7(0.5)$ & 1.7 & 0.30 \\
\hline $\operatorname{PCD}(\mathrm{s})$ & $2.6(0.9)$ & 2.4 & $2.2(0.6)$ & 2.3 & 0.17 \\
\hline $\begin{array}{l}\text { Maximal UES } \\
\text { Pressure }(\mathrm{mmHg})\end{array}$ & $461.9(80.9)$ & 457.5 & $475.6(93.0)$ & 507.4 & 0.73 \\
\hline
\end{tabular}

IRP: integrated relaxation pressure; CFV: contraction front velocity; DCI: distal contraction integral; DL: distal latency; PCE: proximal contraction extension; PCI: proximal contraction integral; PCD: proximal contraction duration; PCD: proximal contraction duration; UES: upper esophageal sphincter. 
The data of IRP of the present investigation suggested the same interpretation, however the difference did not reach statistical significance $(P=0.18)$. It is possible that the number of subjects included in the groups was not large enough to demonstrate a possible difference. Also, the use of a statistical method which takes in consideration the Bayes factor, which include in the analysis the results of similar experiments, could modify the conclusion ${ }^{(9)}$.

HRM is a modern method for esophageal motility evaluation, however the examination performed in different countries did not found the same results ${ }^{(4)}$. The type of HRM system, catheter diameter, demographic factors, body position during the test, consistency of the bolus swallowed and esophageal length have influence on the results of the examination ${ }^{(10)}$.

The IRP is an important measure defined in HRM. It represents the mean esophageal gastric transition pressure measured for four contiguous or non contiguous seconds of relaxation in the 10 seconds window following deglutitive upper esophageal sphincter relaxation ${ }^{(10)}$. An increase in IRP means an outflow obstruction at the esophageal gastric transition ${ }^{(13)}$. If the difference between men and women is true it means that it is necessary to have a normal upper limit value for men and another for women. This investigation was not able to demonstrate this, however it is suggested that the ideal is to have different sets of normal values taking in consideration the factors that could influence the results ${ }^{(10)}$.

This investigation has limitations. If the number of volunteers was higher the results could reach a more conclusive answer. Different characteristics of bolus swallowed, in terms of volume and consistency, could demonstrated a difference between men and women. It not easy to performed HRM in normal volunteers. It is an invasive examination which causes significant discomfort. What was described is that there is no difference between the esophageal motility of men and women however, if difference exist it is likely that do not have clinical implication.

In conclusion, there is no significant difference in esophageal motility between men and women, evaluated in the sitting position with swallows of liquid low viscous bolus.

\section{Author' contributions}

Costa TV had participation in study planning, investigation, data collection and discussion of results, in addition to manuscript preparation and subsequent approval from Arquivos de Gastroenterologia. Dantas RO had participation in study planning, discussion of results and in manuscript preparation and subsequent approval from Arquivos de Gastroenterologia.

Costa TV, Dantas RO. Motilidade do esôfago em homens e mulheres avaliada pela manometria de alta resolução. Arq Gastroenterol. 2017;54(2):145-7.

RESUMO - Contexto - É descrita a existência de diferenças na motilidade de esôfago entre homens e mulheres. A maioria destes trabalhos utilizaram o método de perfusão continua com água para a manometria esofágica. Nesta investigação foi comparada a motilidade do esôfago de homens e mulheres com o método de manometria de alta resolução, realizada na posição sentada e com deglutição de bolo líquido. Objetivo - Comparar a motilidade do esôfago em homens e mulheres, na posição sentada, com o método de manometria de alta resolução. A hipótese é que homens e mulheres têm diferenças na motilidade do esôfago. Métodos - Manometria de alta resolução foi realizada em voluntários saudáveis, 10 homens [média de idade: $37,7(8,1)$ anos] e 12 mulheres [média de idade: 38,7 (7,5) anos], na posição sentada e com 10 deglutições de 5 mL de solução salina. Foram avaliadas a pressão integrada de relaxamento do esfíncter inferior do esôfago, velocidade da contração peristáltica, integral da contração distal, latência distal, extensão da contração proximal, duração da contração proximal $>30 \mathrm{mmHg}$, duração da contração proximal, integral da contração proximal, pressão máxima do esfíncter superior do esôfago. Resultados - Não houve diferença significativa entre homens e mulheres nas variáveis medidas. Conclusão - Não há diferença entre homens e mulheres na motilidade do esôfago avaliada pelo método de manometria de alta resolução, na posição sentada e com deglutição de um bolo líquido.

DESCRITORES - Motilidade gastrointestinal. Manometria, métodos. Fatores sexuais.

\section{REFERENCES}

1. Andrew JM, Heddle R, Hebbard GS, Checklin H, Besanko L Fraser RJ. Age and gender affect likely manometric diagnosis: audit of a tertiary referral hospital clinical esophageal manometry service. J Gastroenterol Hepatol. 2009; 24:125-8.

2. Bernhard A, Pohl D, Fried M, Castell DO, Tutuian R. Influence of bolus consistency and position on esophageal high-resolution manometry findings. Dig Dis Sci. 2008;53:1198-205.

3. Bredenoord AJ, Fox M, Kahrilas PJ, Pandolfino JE, Schwizer W, Smout AJP \& the International High Resolution Manometry Working Group. Chicago classification criteria of esophageal motility disorders defined in high resolution esophageal pressure topography. Neurogastroenterol Motil. 2012;24(Suppl.1):57-65.

4. Carmo GC, Jafari J, Sifrim D, Oliveira RB. Normal esophageal pressure topography metrics for data derived from the Sandhill-Unisensor high-resolution manometry assembly in supine and sitting positions. Neurogastroenterol Motil. 2015;27:285-92.

5. Dalmazo J, Aprile LRO, Dantas RO. Esophageal contractions, bolus transit and perception of transit after swallows of liquid and solid boluses in normal subjects. Arq Gastroenterol. 2012;49:250-4.

6. Dalmazo J, Aprile LRO, Dantas RO. Effect of swallowed bolus viscosity and body position on esophageal transit, contraction and perception of transit. Arq Gastroenterol. 2015;52:27-31.
7. Dantas RO, Alves LMT, Cassiani RA. Gender differences in proximal esophageal contractions. Arq Gastroenterol. 2009;46:284-7.

8. Dantas RO, Ferriollli E, Souza MAN. Gender effects on esophageal motility. Braz J Med Biol Res. 1998;31:539-44.

9. Goodman SN. Toward evidence-based medical statistics. 2: The Bayes factor. Ann Inter Med. 1999;130:1005-13.

10. Herregods TVK, Roman S, Kahrilas PJ, Smout AJPM, Bredenoord AJ. Normative values in esophageal high-resolution manometry. Neurogastroenterol Motil. 2015;27:175-87.

11. Jung KW, Jung HY, Myung SJ, Kim SO, Lee J, Yoon IJ, et al. The effect of age on the key parameters in the Chicago Classification: a study using high-resolution esophageal manometry in asymptomatic normal individuals. Neurogastroenterol Motil. 2015;27:246-57.

12. Roman S, Damon H, Pellissier PE, Mion F. Does body position modify the results of esophageal high resolution manometry? Neurogastroenterol Motil. 2010;22:271-5.

13. van Hoeij FB, Bredenoord AJ. Clinical application of esophageal high-resolution manometry in the diagnosis of esophageal motility disorders. J Neurogastroenterol Motil. 2016;22:6-13.

14. Vega KJ, Palácio C, Langford-Legg T, Watts J, Jamal MM. Gender variation in oesophageal motor function: analysis of 129 healthy individuals. Dig Liv Dis. 2010;42:482-4. 